\title{
The Chemopreventive Effect of Taxifolin Is Exerted through ARE-Dependent Gene Regulation
}

\author{
Saet Byoul Lee, ${ }^{a}$ Kwang Hyun Cha, ${ }^{a}$ Dangaa Selenge, ${ }^{b}$ Amgalan Solongo, ${ }^{b}$ and Chu Won Nho*,a \\ ${ }^{a}$ Natural Products Research Center, Korea Institute of Science and Technology; Gangneung Techno Valley, Gangneung, \\ Gangwon-do, 210-340, Korea: and ${ }^{b}$ Institute of Chemical and Chemical Technology; 51 Ulaanbaatar, Mongolia. \\ Received December 29, 2006; accepted March 14, 2007
}

Phase II detoxification enzymes are responsible for the detoxification and elimination of activated carcinogens, and thus act as important biomarkers for chemoprevention. In this study, we tested the chemopreventive activity of taxifolin, a flavanon compound purified from a mongolian medicinal plant, by measuring quinone reductase $(\mathrm{QR})$ activity in HCT 116 cells. Taxifolin induced significant $\mathrm{QR}$ activity, but displayed relatively low cytotoxicity in cells $($ chemoprevention index $=5.75)$. To identify the target genes regulated by taxifolin, DNA microarray was performed with a $3 \mathrm{~K}$ human cancer chip containing 3096 human genes associated with carcinogenesis. Significant analysis of microarray (SAM) revealed 428 differentially expressed (DE) genes as statistically significant, with a false discovery rate $($ FDR $)$ of $57.2 \%($ delta $=0.3366)$. Sixty-five genes, including a few detoxification enzymes (NQO1, GSTM1) and an antioxidant enzyme (TXNRD1), were up-regulated and 363 genes were down-regulated in the presence of $60 \mu \mathrm{M}$ taxifolin. In view of the finding that selected genes of interest contained antioxidant response element (ARE), we hypothesize that taxifolin modulates chemopreventive genes through activation of the ARE. Transient transfection experiments using the ARE QR-CAT construct demonstrate that taxifolin significantly activates ARE, but not xenobiotic response element (XRE). In conclusion, taxifolin acts as a potential chemopreventive agent by regulating genes via an ARE-dependent mechanism.

Key words taxifolin; antioxidant response element; detoxification enzyme; chemoprevention

Cancer is one of leading causes of death worldwide, and prevention of cancer is a preferable option to chemotherapy. Cancer chemoprevention is defined as the pharmacological administration of synthetic or naturally occurring compounds in plants (phytochemicals) that prevent, inhibit or reverse carcinogenesis, or prevent the development of invasive cancer. ${ }^{1)}$ Flavonoids, a group of phytochemicals (naturally occurring polyphenolic compounds), are most prevalent in vegetables, nuts, fruits, as well as medicinal herbs. ${ }^{2}$ Flavonoid classes include chalcones, flavones, flavonols, flavanones, anthocyanins and isoflavones. Notably, flavonoids have a wide range of biochemical and pharmacological properties, with one of the most extensively characterized effects being cancer chemoprevention. To develop novel chemopreventive agents, the molecular mechanisms of the agents require elucidation. One suggested mechanism of chemoprevention by flavonoids is the modulation of detoxification enzymes involved in metabolic activation and excretion of carcinogens. ${ }^{3)}$ Larix sibirica is one of mongolian medicinal plants used in this study and the wood contains up to $4 \%$ of flavonoids including quercetin, taxifolin, and kaempferol (personal communication with Dr. A. Solongo). Numerous studies have reported chemopreventive effects of quercetin and kaempferol in terms of phase II detoxification enzyme induction ${ }^{4-7)}$ while almost no studies have performed for investigating chemopreventive effects of taxifolin. Thus, we focused on evaluation of chemopreventive effects of taxifolin, a flavanone compound isolated from Larix sibirica, by examining phase II detoxification enzyme inducibility and its mode of action.

The potential chemopreventive agents regulating detoxification enzymes are divided into two groups, designated mono- and bifunctional inducers. Monofunctional inducers upregulate a number of phase II detoxification enzymes, including quinone reductase $(\mathrm{QR}$, also known as
NAD(P)H : quinone oxidoreductase, NQO1) and glutathione$S$-transferases (GST). Bifunctional inducers upregulate a similar array of phase II enzymes, in addition to a few phase I enzymes, including CYP1A1. Phase I enzymes are involved in the bioactivation of carcinogens. Thus, monofunctional inducers are closely related to chemoprevention, relative to bifunctional inducers. ${ }^{8)}$ Two mechanisms of control of genes representing detoxification enzymes by chemopreventive agents have been identified, which involve two regulatory elements. The antioxidant response element (ARE) is associated with induction of phase II detoxification enzymes (monofunctional induction), while xenobiotic response element (XRE) functions in the induction of both phase II and some phase I cytochrome P450 enzymes (bifunctional induction). Both ARE and XRE are present in the QR and GST enzymes, ${ }^{9,10)}$ whereas XRE, but not ARE, is present in the regulatory region for cytochrome P450 1A (CYP1A). ${ }^{11)}$

An important strategy for the development of chemopreventive agents is the clarification of molecular functions related to anti-cancer effects. Tools such as genomics, proteomics, transcriptomics and metabolomics are highly useful for investigating the mechanisms of potential chemopreventive agents at the molecular level. ${ }^{12)}$ Gene expression patterns can be profiled by microarray technology, which is a useful tool for identifying novel biomarkers and molecular targets for chemoprevention. In this study, we examine differential gene regulation by a potential chemopreventive agent, taxifolin, using microarray technology, with the aim of establishing its mechanism of action.

\section{MATERIALS AND METHODS}

Plant Material Fresh Larix sibirica LDB. were collected from Mongolia during July and August, and the voucher specimens (Voucher No. ICCT-2005-M45) were deposited at 


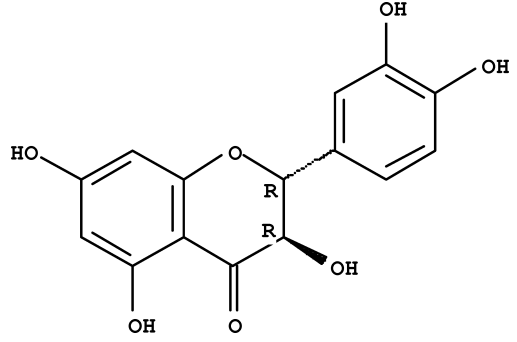

Fig. 1. Chemical Structure of Taxifolin (Dihydroquercetin, 3,3',4',5,7Pentahydroxy Flavanone) Isolated from the Mongolian Medicinal Plant, Larix sibirica LDB.

the Herbarium of the Institute of Chemistry and Chemical Technology, Ulaanbaatar, Mongolia.

Isolation and Identification of Taxifolin The dried plant was extracted three times with water by refluxing for $5 \mathrm{~h}$. After removal of the solvent in vacuo, the residue was suspended in water, and extracted with $n$-hexane and ethyl acetate to obtain an $n$-hexane and ethyl acetate soluble fraction. A proportion of the ethyl acetate fraction was purified by chromatography on a silica gel eluted with hexane and increasing proportions of ethyl acetate, followed by recrystallization in methanol. The compound was identified as taxifolin by EI-Mass, NMR spectra, and direct comparison with authentic compounds. The compound was $>95 \%$ pure. The chemical structure is depicted in Fig. 1.

Cell Culture HCT116 cells were obtained from the American Type Culture Collection (Rockville, MD, U.S.A.) and the cells were maintained at subconfluence in $95 \%$ air and $5 \% \mathrm{CO}_{2}$ humidified atmosphere at $37^{\circ} \mathrm{C}$. Minimum Essential Medium (MEM, JBI, Korea) was supplemented with $10 \%$ fetal bovine serum (FBS), penicillin (100 units $/ \mathrm{ml}$ ), and streptomycin $(100 \mu \mathrm{g} / \mathrm{ml})$. The cells were counted with a hemocytometer, and the number of viable cells determined by trypan blue dye exclusion.

MTT Cytotoxicity Assay The cytotoxicity of taxifolin was evaluated using the Cell Counting Kit (CCK-8) produced by Dojindo Laboratories (Tokyo, Japan). In brief, HCT116 cells $\left(1 \times 10^{4}\right.$ cells per well $)$ were plated onto 96well plates, incubated at $37^{\circ} \mathrm{C}$ for $24 \mathrm{~h}$, and the cells were treated with various concentrations of taxifolin. After $24 \mathrm{~h}$, $10 \mu \mathrm{l}$ of CCK- 8 solution was added to the wells, and incubation continued for another $3 \mathrm{~h}$. The resulting color was assayed at $450 \mathrm{~nm}$ using a PowerWave ${ }^{\mathrm{TM}}$ XS Microplate Spectrophotometer reader (Bio-Tek Instruments, Winooski, VT, U.S.A.).

Quinone Reductase Assay QR induction activities were determined using the Prochaska modified bioassay with minor modifications. ${ }^{13)}$ HCT116 cells $\left(1 \times 10^{4}\right.$ cells per well $)$ were plated onto 96-well plates (Techo Plastic Products AG, Trasadingen, Switzerland), and incubated for $24 \mathrm{~h}$ prior to treatment. Growth media containing $0.1 \% \mathrm{Me}_{2} \mathrm{SO}$ or $2.5 \mu \mathrm{M}$ sulforaphane were used as a negative and positive control, respectively. Treated cells were rinsed with phosphate buffered saline (pH 7.4), lysed with $80 \mu \mathrm{l}$ of $0.08 \%$ digitonin in $2 \mathrm{~mm}$ EDTA, incubated for $30 \mathrm{~min}$, and the QR assay performed. The total protein content was measured with the Bio-Rad assay. A $200 \mu \mathrm{l}$ aliquot of mixed solution [ $49 \mathrm{ml}$ of $25 \mathrm{~mm}$ Tris buffer; $34 \mathrm{mg}$ of BSA; $0.34 \mathrm{ml}$ of $1.5 \%$ Tween-20 solution; $0.34 \mathrm{ml}$ of thawed cofactor solution (150 mM glucose-6- phosphate, 4.5 mm NADP, 0.75 mm FAD in Tris buffer); 100 units of glucose-6-phosphate dehydrogenase; $15 \mathrm{mg}$ of MTT, 3-(4,5-dimethylthiazo-2-yl)-2,5-diphenyltetrazolium bromide; and $50 \mu \mathrm{l}$ of $50 \mathrm{~mm}$ menadione in acetonitrile] was added to a $50 \mu \mathrm{l}$ aliquot of cell lysates. Samples were measured at $610 \mathrm{~nm}$ five times at $50 \mathrm{~s}$ intervals, using a PowerWave ${ }^{\mathrm{TM}} \mathrm{XS}$ Microplate Spectrophotometer reader (Bio-Tek Instruments, Winooski, VT, U.S.A.). After completion of the readings, $50 \mu \mathrm{l}$ of $0.3 \mathrm{~mm}$ dicumarol in $25 \mathrm{~mm}$ Tris buffer was added into each well, and the plate was read again under similar conditions. QR activity was calculated by comparing the QR specific activities of compound-treated cells with those of control-treated cells.

Microarray Analysis Experiments were performed on Human Cancer $3.0 \mathrm{~K}$ oligo microarrays purchased from GenoCheck, Korea. A Platinum Human Cancer 3.0K oligo microarray consists of 3096 oligonucleotide spots made in Operon (Huntsville, AL, U.S.A.). Total RNA was extracted from the treated and untreated HCT116 cell line using TRIZOL (Invitrogen, NY, U.S.A.), and further purified on RNeasy midi kit columns (Qiagen, CA, U.S.A.), following the manufacturer's protocol. Fluorescence-labeled cDNA probes were prepared from $30 \mu \mathrm{g}$ of total RNA by oligo $(\mathrm{dT})_{18}$-primed polymerization using SuperScript II reverse transcriptase (Invitrogen, NY, U.S.A.) in a total reaction volume of $30 \mu \mathrm{l}$. The reverse transcription mixture included 400 U Superscript RNaseH-reverse transcriptase (Invitrogen, NY, U.S.A.), $15 \mathrm{~mm}$ dATP, dTTP and dGTP, $0.6 \mathrm{~mm}$ dCTP and $3 \mathrm{~mm}$ Cy 3 or Cy5 labeled dCTP (NEN Life Science Product Inc.). The labeled cDNA mixture was concentrated by ethanol precipitation, and resuspended in $10 \mu \mathrm{l}$ of hybridization solution (GenoCheck, Korea). Two labeled cDNAs were mixed, and denatured at $95^{\circ} \mathrm{C}$ for $2 \mathrm{~min}$. Slides were hybridized for $12 \mathrm{~h}$ at $62{ }^{\circ} \mathrm{C}$ in a hybridization chamber. Hybridized slides were washed in $2 \times \mathrm{SSC}, 0.1 \% \mathrm{SDS}$ for $2 \mathrm{~min}$, $1 \times \mathrm{SSC}$ for $3 \mathrm{~min}$, followed by $0.2 \times \mathrm{SSC}$ for $2 \mathrm{~min}$ at room temperature. Slides were centrifuged at $3000 \mathrm{rpm}$ for $20 \mathrm{~s}$ for drying. Hybridized slides were scanned with the Axon Instruments GenePix 4000B scanner. Scanned images were analyzed with the software programs GenePix Pro 5.1 (Axon CA, U.S.A.) and GeneSpring 7.0 (Sillicongenetics, CA, U.S.A.), R package. The statistical significance of microarray data was confirmed by Statistical Analysis of Microarray (SAM; Stanford Univ., CA, U.S.A.). Statistical procedures, such as SAM, were applied for detecting a set of differentially expressed (DE) genes from the final data set. ${ }^{14)}$

Real-Time PCR The accuracy of microarray analyses was confirmed by Real-time PCR analysis. Real-time quantitative PCR was performed in triplicate in 384-well plates. The primers designed for Real-time PCR experiment were summarized in Table 2. Each $20 \mu \mathrm{l}$ reaction consisted of $10 \mu \mathrm{l}$ of SYBR Green Master Mix (Applied Biosystems), and $0.8 \mu \mathrm{l}$ of $10 \mathrm{pm}$ forward and reverse primers. The following conditions were applied: $50^{\circ} \mathrm{C}$ for $2 \mathrm{~min}$ and $95^{\circ} \mathrm{C}$ for $10 \mathrm{~min}$, followed by 40 cycles of $95^{\circ} \mathrm{C}$ for $30 \mathrm{~s}$ and $60^{\circ} \mathrm{C}$ for $30 \mathrm{~s}$, and $72^{\circ} \mathrm{C}$ for $30 \mathrm{~s}$. Real-time PCR analysis was performed on an Applied Biosystems Prism 7900 Sequence Detection System (Applied Biosystems, Foster City, CA, U.S.A.). The Student $t$-test was used to assess the differences between treated and control groups. Differences with $p$-values $<0.05$ were considered statistically significant. 
Table 1. Genes of Interest Modulated by Taxifolin in HCT116 Cells

\begin{tabular}{|c|c|c|c|}
\hline Gene symbol & Gene name & Accession number & Fold change \\
\hline \multicolumn{4}{|l|}{ Up-regulation } \\
\hline XPA & Xeroderma pigmentosum, complementation group A & NM_000380 & $3.1 \pm 1.182$ \\
\hline XRCC4 & $\mathrm{X}$-ray repair complementing defective repair in Chinese hamster cells 4 & NM_022550 & $2.3 \pm 1.542$ \\
\hline GDF15 & Growth differentiation factor 15 & NM_004864 & $2.5 \pm 0.263$ \\
\hline GAS6 & Growth arrest-specific 6 & NM_000820 & $2.5 \pm 1.045$ \\
\hline TRAF3 & TNF receptor-associated factor 3 & AF110908 & $2.4 \pm 0.405$ \\
\hline DCC & Deleted in colorectal carcinoma & NM_005215 & $2.1 \pm 0.488$ \\
\hline NQO1 & $\mathrm{NAD}(\mathrm{P}) \mathrm{H}$ dehydrogenase, quinone 1 & NM_000903 & $2.4 \pm 0.283$ \\
\hline TXNRD1 & Thioredoxin reductase 1 & NM_003330 & $1.8 \pm 0.031$ \\
\hline GSTM1 & Glutathione $S$-transferase M1 & NM_000561 & $1.7 \pm 0.097$ \\
\hline \multicolumn{4}{|c|}{ Down-regulation } \\
\hline CYP2E1 & Cytochrome P450, family 2 , subfamily E, polypeptide 1 & NM_000773 & $0.6 \pm 0.070$ \\
\hline JUN & V-jun sarcoma virus 17 oncogene homolog (avian) & NM_002228 & $0.5 \pm 0.018$ \\
\hline CCNA1 & Cyclin A1 & NM_003914 & $0.4 \pm 0.083$ \\
\hline CDC25A & Cell division cycle $25 \mathrm{~A}$ & NM_001789 & $0.5 \pm 0.044$ \\
\hline RASA1 & RAS p21 protein activator (GTPase activating protein) 1 & NM_002890 & $0.4 \pm 0.021$ \\
\hline PDGFB & Platelet-derived growth factor beta polypeptide (simian sarcoma viral (v-sis) oncogene homolog) & NM_002608 & $0.3 \pm 0.048$ \\
\hline FGF18 & Fibroblast growth factor 18 & NM_003862 & $0.3 \pm 0.017$ \\
\hline EGF & Epidermal growth factor (beta-urogastrone) & NM_001963 & $0.3 \pm 0.066$ \\
\hline FGF3 & $\begin{array}{l}\text { Fibroblast growth factor } 3 \text { (murine mammary tumor virus integration site (v-int-2) } \\
\text { oncogene homolog) }\end{array}$ & NM_005247 & $0.3 \pm 0.057$ \\
\hline
\end{tabular}

Table 2. Primer Sets of Selected Genes for Real-Time PCR

\begin{tabular}{|c|c|c|c|}
\hline Gene name & Forward primer sequence & Reverse primer sequence & Size (bp) \\
\hline CYP2E1 & TTC AGC GGT TCA TCA CCC T & GAG GTA TCC TCT GAA AAT GGT GTC & 77 \\
\hline NQO1 & GGC AGA AGA GCA CTG ATC GTA & TGA TGG GAT TGA AGT TCA TGG C & 145 \\
\hline$T X N R D 1$ & TCC TAT GTC GCT TTG GAG TGC & GGA CCT AAC CAT AAC AGT GAC GT & 72 \\
\hline
\end{tabular}

Transient Transfection and Reporter Gene Assay HCT116 cells $\left(5 \times 10^{4} / \mathrm{ml}\right)$ were cultured in 24 -well tissue culture plates for $24 \mathrm{~h}$ before transfection at $70-80 \%$ confluency. Cells were transiently co-transfected with $2.5 \mu \mathrm{g}$ of one of three different reporter constructs containing either the antioxidant response element (ARE QR-CAT) or the xenobiotic response element (XRE QR-CAT) or the empty vector (pCAT-BASIC) derived from the rat QR gene in combination. ${ }^{10)}$ All CAT reporter gene constructs were a gift from Dr. Cecil Pickett (Schering-Plough Research Institute, NJ, U.S.A.). After $24 \mathrm{~h}$ of treatment, cells were lysed and assayed for CAT expression using a CAT-ELISA kit (Roche Biochemicals, Indianapolis, IN, U.S.A.), following the manufacturer's instructions. 3-Methylcholanthrene (Sigma, St. Louis, MO, U.S.A.), a typical XRE activator, was used as a positive control in this experimental system. CAT expression was normalized with respect to protein concentration, which was determined with the Bio-Rad protein assay kit (Bio-Rad, Hercules, CA, U.S.A.) and presented as fold induction over the control.

\section{RESULTS}

Chemopreventive Activity of Taxifolin in HCT116 Cells To determine the ability of taxifolin to induce QR activity, dose-dependent experiments were performed in human colonic HCT116 cells. QR specific activity was measured after $48 \mathrm{~h}$ of taxifolin treatment of HCT116 cells at a broad range of concentrations $(3.9-250 \mu \mathrm{M})$. As shown in Fig. 2, taxifolin induced a moderate increase in QR activity (maxi-

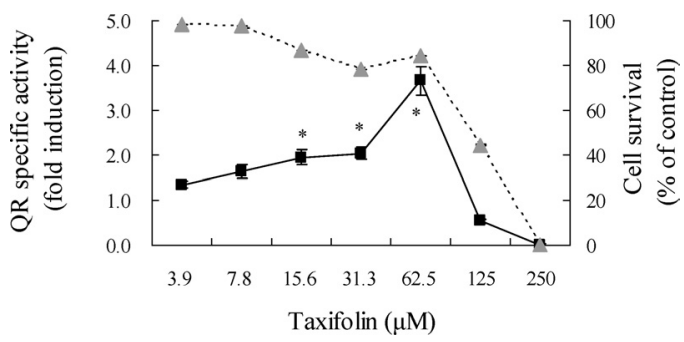

Fig. 2. Effect of Taxifolin on QR Specific Activity and Cytotoxicity in HCT116 Cells

HCT116 cells were treated with taxifolin for $24 \mathrm{~h}$ and the final concentration in the cell culture medium is indicated. QR activity was expressed as a fold induction over a control with no inducer. Cell survival was expressed as a \% of control with no inducer. The bars indicate averages and standard deviation of experiments performed in triplicate. Square and triangle indicate QR specific activity and cytotoxicity, respectively. An asterisk denotes significant differences from control $(* p<0.05)$ using Student's $t$ test, with $n=3$.

mum of 3.65 -fold) at a concentration range of 31.3 to $62.5 \mu \mathrm{M}$, while $\mathrm{QR}$ activity was decreased at higher concentrations $(125-250 \mu \mathrm{M})$ due to cytotoxicity. Taxifolin was cytotoxic to HCT116 cell lines, with an $\mathrm{IC}_{50}$ value of 63.42 . The CD of taxifolin was $11.03 \mu \mathrm{M}$, leading to a CI value of 5.75 .

Modulation of Cancer-Related Gene Expression Profiles by Taxifolin Assuming that taxifolin is a potential chemopreventive agent affecting the expression of certain innate genes associated with detoxification, we analyzed gene expression profiles in the presence of the compound. To identify the target genes related to cancer, DNA microarray was performed with a $3.0 \mathrm{~K}$ human cancer chip, as described in 


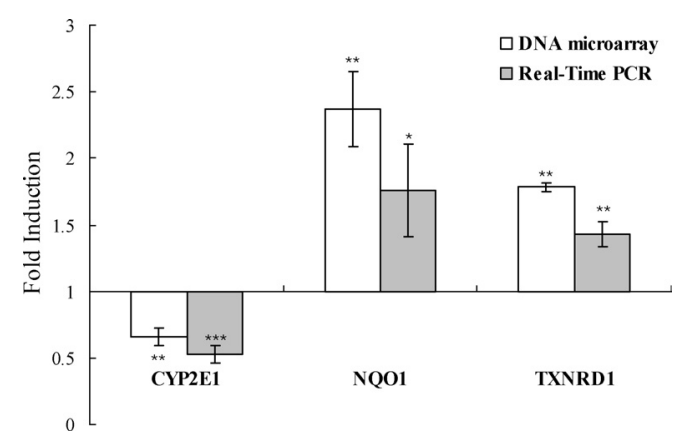

Fig. 3. Expression Plot of Selected Genes with Real-Time PCR Analysis and DNA Microarray Analysis in the Presence of Taxifolin

The bars indicate averages and standard deviation of experiments performed in triplicate. Bars marked with asterisks are significantly different from control $(* p<0.05$, $* * p<0.01, * * * p<0.005)$ using Student's $t$ test with $n=3$.

Materials and Methods. Cells were treated with taxifolin at the $\mathrm{IC}_{50}$ value $(60 \mu \mathrm{M})$ for $48 \mathrm{~h}$, and RNA was extracted after $48 \mathrm{~h}$, labeled, and hybridized to the cancer chip comprising 3096 human genes associated with carcinogenesis. Expression levels were analyzed in a one-class response using significant analysis of microarray (SAM). In total, $428 \mathrm{DE}$ genes were statistically significant, with a false discovery rate $($ FDR $)$ of $57.2 \%$ (delta=0.3366). Sixty-five genes were upregulated and 363 genes down-regulated in the presence of $60 \mu \mathrm{M}$ taxifolin (Table 1). With respect to "fold change", two of the upregulated genes, NQO1 and GSTM1, were members of the phase II detoxification enzymes, while one of the downregulated genes, $C Y P 2 E 1$, was a phase I detoxification enzyme. Upregulation of NQO1 was consistent with the induction of quinone reductase specific activity by taxifolin (Fig. 2). Thioredoxin reductase 1 (TXNRD1), a selenium (Se)-dependent enzyme with in vitro antioxidant activity, was also significantly upregulated by taxifolin. In contrast, mammalian growth related factors, $P D G F B, F G F 18, F G F 3, E G F$, and cell cycle-related genes, $C C N A 1$ and $C D C 25 A$, were significantly downregulated in the presence of taxifolin.

Modulation of Detoxification Enzyme Genes Observed Using Quantitative Real-Time PCR We performed additional mRNA expression analysis of selected genes of interest, including those encoding phase II and phase I detoxification enzymes, $N Q O 1$ and $C Y P 2 E 1$, respectively. Relative mRNA levels obtained using DNA microarray were reasonably consistent with Real-Time PCR data (Fig. 3). Taxifolin $(60 \mu \mathrm{M})$ is associated with a significant increase in the mRNA level of phase II detoxification enzymes, specifically, NQO1 (1.8-fold, $p<0.05)$, and decrease in CYP2E1, a phase I detoxification enzyme $(-0.6$ fold, $p<0.005)$. We additionally analyzed $T X N R D 1$, a selenium-dependent antioxidant enzyme, ${ }^{15)}$ identified by DNA microarray. This gene contains ARE, a cis-acting element in the promoter regions of numerous phase II and antioxidant genes responding to chemopreventive agents. TXRND1 mRNA was significantly increased in the presence of taxifolin, in accordance with DNA microarray results.

Activation of Antioxidant Response Element by Taxifolin Talalay and colleagues have referred to compounds that stimulate both XRE- and ARE-driven gene expression designated 'bifunctional inducers'. ${ }^{8)}$ In contrast, compounds that transcriptionally activate genes through ARE, but not
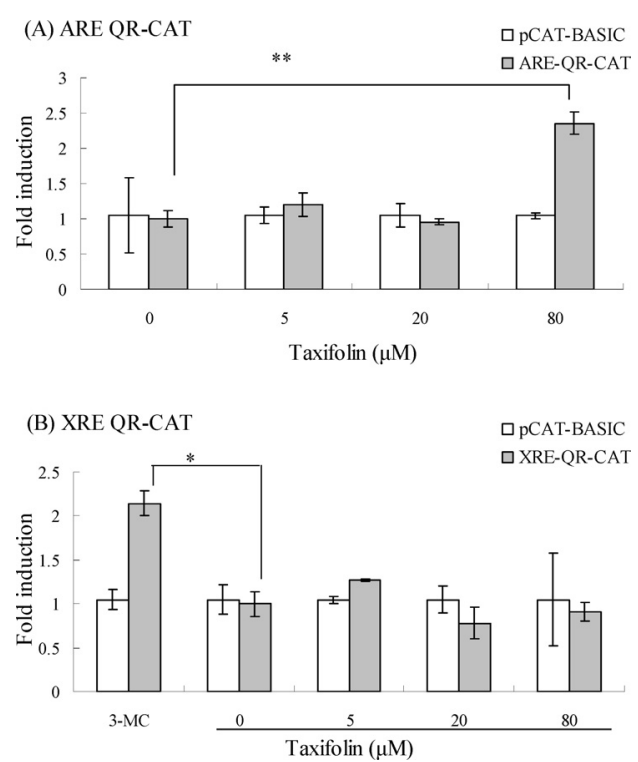

Fig. 4. Dose-Dependent CAT Expression by Taxifolin in HCT116 Cells

The cells were transfected with either ARE QR-CAT or XRE AR-CAT or pCATBASIC (empty vector) construct for $24 \mathrm{~h}$. After $24 \mathrm{~h}$ treatment with taxifolin, the cells were subjected to a CAT-ELISA assay. The normalization of CAT expression was determined using the protein concentration present in each sample, and expressed as fold-induction of the control. 3-Methylcholanthrene (3-MC) was used as a positive control for $\mathrm{XRE}$ activation. The bars marked with an asterisk are significantly different from control $(* p<0.05, * * p<0.01)$ using Student's $t$ test, with $n=3$.

XRE, are designated 'monofunctional inducers' ${ }^{8)}$ To determine the ability of a taxifolin to induce ARE- or XREdriven gene expression, we transiently transfected HCT116 cells with a CAT reporter construct containing either the ARE consensus (ARE QR-CAT) or XRE consensus (XRE QR-CAT). CAT activity was measured after treatment with taxifolin $(5-80 \mu \mathrm{M})$. ARE was significantly activated (by about 2-fold) by $80 \mu \mathrm{M}$ taxifolin, while XRE was not activated at any of the concentrations tested (Fig. 4).

\section{DISCUSSION}

Flavonoid natural products display a wide range of biochemical and pharmacological properties, with one of the most thoroughly characterized effects being chemopreventive activity. These chemopreventive effects of flavonoids are possibly exerted through a variety of mechanisms, including modification of detoxification enzymes ${ }^{16,17)}$ and free radical scavenging. ${ }^{18)}$ The chemopreventive index is a useful marker for the screening of potential agents. Taxifolin exhibits high detoxification ability but lower cytotoxicity in cells, representative of a high chemopreventive index. To determine whether this high chemopreventive activity results from the transcriptional regulation of anti-cancer related genes, we performed DNA microarray using a $3.0 \mathrm{~K}$ cancer chip. Taxifolin modulated the expression of several genes, including those coding for detoxification enzymes, cell cycle regulatory proteins, growth factors, and DNA repair proteins (Table 1). The most effective genes for chemoprevention are hepatic detoxification enzymes, including quinone reductase (NQO1), glutathione- $S$-transferases $(G S T)$, glutathione reductase, glucose-6-phosphate dehydrogenase, and epoxide hydrolase. Our microarray results show that the phase II detoxification enzymes, NQO1 and GSTM1, are upregulated, while the 
phase I detoxification enzyme, $C Y P 2 E 1$, is downregulated in the presence of taxifolin. A small percentage (2 to 4\%) of the human population worldwide contains both mutant alleles. These individuals are deficient in QR and more susceptible to benzene toxicity and leukemia. ${ }^{19,20)}$ A more recent study shows that QR - / - mice exhibit increased susceptibility to benzopyrene (BP)-induced skin tumors. ${ }^{21)}$ Based on these findings, it is reasonable to suggest that $\mathrm{QR}$ is an endogenous protector against carcinogenesis, and thus a promising biomarker to determine the chemopreventive effects of a variety of compounds. Another detoxification enzyme that is upregulated in our microarray is GSTM1. Recent epidemiological studies report that the GSTM1-null genotype increases the risk for gastric and thyroid cancers. ${ }^{22,23)}$ A substantial number of GST genes contain ARE or related sequences. For instance, $Q R$ and GSTMI contain ARE or ARE-like sequences in the regulatory regions. ${ }^{24)}$ Thus, taxifolin may trigger AREdependent mechanisms for upregulating $Q R$ and GSTM1. Yet another interesting gene identified in this study is thioredoxin reductase (TXNRD1), which encodes a selenium-dependent antioxidant enzyme. However, its exact role in cancer remains to be defined. Notably, selenium supplementation significantly decreases prostate cancer, as well as total cancer incidence in a long-term double blind study. ${ }^{25)} \mathrm{A}$ recent report shows that thioredoxin reductase is transcriptionally regulated in response to chemopreventive agents via an ARE located at the $5^{\prime}$-flanking region of the gene. ${ }^{26)}$ Therefore, activation of ARE appears to be the common anticancer mechanism of detoxification and antioxidant enzymes. Here we observe that taxifolin activates ARE, but not XRE, implying that the compound exerts its chemopreventive effects through an ARE-dependent mechanism regulating anticancer-related genes encoding detoxification and antioxidant enzymes (Fig. 4).

Nrf2 is an essential transcription activator of ARE that responds to various chemopreventive agents, ${ }^{27)}$ as evident from a comparison study between $\mathrm{Nrf} 2$ knockout and wild-type mice. ${ }^{28)}$ Susceptibility to carcinogenesis is markedly increased when phase II detoxification enzyme levels are suppressed in Nrf2 knockout mice. Keap1, the other member of the cytoplasmic oxidative stress system, is an inhibitor of $\mathrm{Nrf2}$, which binds to its $\mathrm{N}$-terminal region forming a Nrf2Keap1 complex. ${ }^{27)}$ Activation of the Nrf2-Keap1 complex and subsequent degradation of Keap1, followed by nuclear translocation of Nrf2, is triggered by phase II detoxification enzymes and oxidative stress through ARE. ${ }^{29)}$ Recent studies disclose that a number of flavonoids upregulate the Nrf2 gene in association with ARE activation. Quercetin glycosides increase the level of nuclear Nrf2 and reporter gene activity ${ }^{30)}$ and epigallocatechin-3-gallate (EGCG) upregulates Nrf2 levels in nuclear extracts, along with ARE activation. ${ }^{31}$ The ARE-containing genes upregulated by taxifolin in our experiments may also be modulated by the Nrf2-Keap 1 complex. However, these mechanisms require further investigation.

Ethanol-inducible CYP2E1, a phase I detoxification enzyme, is a key protein in the fields of toxicology and carcinogenesis. ${ }^{32)}$ Some flavonoids inhibit CYP2E1 activity, resulting in anti-carcinogenic effects. Genistein and equol, isoflavones in soy products, inhibit CYP2E1 metabolism in acetone-induced mice by blocking aryl hydroxylation of $p$ - nitrophenol (CYP2E1 substrate) by CYP2E1. ${ }^{33)}$ Theaflavins and catechins in black tea suppress CYP2E1 protein expression in rat intestinal microsomes after oral intake for four weeks. ${ }^{34)}$ Thus, the simultaneous inhibition of CYP2E1 and induction of NQO1 in our experiments implies that taxifolin exerts chemopreventive effects through modulating the balance between phase I and II detoxification reactions.

In conclusion, taxifolin isolated from a Mongolian medicinal plant exerts chemopreventive effects through activation of ARE. Taxifolin additionally modulates cancer-related genes, including those involved in hepatic detoxification, antioxidation, cell cycle, and cell growth, as demonstrated by DNA microarray using a cancer DNA chip. Thus, taxifolin is a potential chemopreventive agent that acts by targeting ARE-containing genes in non-transformed or preneoplastic cells of the human colon. Other genes modulated by taxifolin identified in this study will be further investigated to identify novel targets of chemoprevention agents for treating human colon cancers, and therefore warrant further investigation.

Acknowledgements This work was supported by the grants Korea-Mongolia International Joint Project, Ministry of Science and Technology (MOST). We are thankful to Dr. Byoung Sung Ahn for his support through Korea-Mongolia Science and Technology Cooperation Project, Korea Science and Engineering Foundation (KOSEF).

\section{REFERENCES}

1) Park E. J., Pezzuto J. M., Cancer Metastasis Rev., 21, 231-255 (2002).

2) Hollman P. C., Katan M. B., Biomed. Pharmacother, 51, 305-310 (1997).

3) Talalay P., Fahey J. W., Holtzclaw W. D., Prestera T., Zhang Y., Toxicol. Lett., 82-83, 173-179 (1995).

4) Rodgers E. H., Grant M. H., Chem. Biol. Interact., 116, 213-228 (1998).

5) Valerio L. G., Jr., Kepa J. K., Pickwell G. V., Quattrochi L. C., Toxicol. Lett., 119, 49-57 (2001).

6) Yannai S., Day A. J., Williamson G., Rhodes M. J., Food Chem. Toxicol., 36, 623-630 (1998).

7) Oakley G. G., Loberg L. I., Yao J., Risinger M. A., Yunker R. L., Zernik-Kobak M., Khanna K. K., Lavin M. F., Carty M. P., Dixon K., Mol. Biol. Cell., 12, 1199-1213 (2001).

8) Prochaska H. J., Talalay P., Cancer Res., 48, 4776-4782 (1988).

9) Rushmore T. H., Pickett C. B., J. Biol. Chem., 265, 14648-14653 (1990).

10) Favreau L. V., Pickett C. B., J. Biol. Chem., 266, 4556- 4561 (1991).

11) Okey A. B., Riddick D. S., Harper P. A., Toxicol. Lett., 70, $1-22$ (1994).

12) Michener C. M., Ardekani A. M., Petricoin E. F., 3rd, Liotta L. A., Kohn E. C., Cancer Detect. Prev., 26, 249-255 (2002).

13) Fahey J. W., Dinkova-Kostova A. T., Stephenson K. K., Talalay P., Methods Enzymol., 382, 243-258 (2004).

14) Tusher V. G., Tibshirani R., Chu G., Proc. Natl. Acad. Sci. U.S.A., 98 5116-5121 (2001).

15) Mustacich D., Powis G., Biochem. J., 346, 1-8 (2000).

16) Canivenc-Lavier M. C., Vernevaut M. F., Totis M., Siess M. H., Magdalou J., Suschetet M., Toxicology, 114, 19-27 (1996).

17) Shih H., Pickwell G. V., Quattrochi L. C., Arch. Biochem. Biophys., 373, 287-294 (2000).

18) Raso G. M., Meli R., Di Carlo G., Pacilio M., Di Carlo R., Life Sci., 68, 921-931 (2001).

19) Larson R. A., Wang Y., Banerjee M., Wiemels J., Hartford C., Le Beau M. M., Smith M. T., Blood, 94, 803-807 (1999).

20) Rothman N., Smith M. T., Hayes R. B., Traver R. D., Hoener B., Campleman S., Li G. L., Dosemeci M., Linet M., Zhang L., Xi L., Wacholder S., Lu W., Meyer K. B., Titenko-Holland N., Stewart J. T., Yin 
S., Ross D., Cancer Res., 57, 2839-2842 (1997).

21) Long D. J., 2nd, Waikel R. L., Wang X. J., Perlaky L., Roop D. R., Jaiswal A. K., Cancer Res., 60, 5913-5915 (2000).

22) Lai K. C., Chen W. C., Tsai F. J., Li S. Y., Chou M. C., Jeng L. B., Hepatogastroenterology, 52, 1916-1919 (2005).

23) Morari E. C., Leite J. L., Granja F., da Assumpcao L. V., Ward L. S., Cancer Epidemiol. Biomarkers Prev., 11, 1485-1488 (2002).

24) Hayes J. D., Flanagan J. U., Jowsey I. R., Annu. Rev. Pharmacol. Toxicol., 45, 51-88 (2005)

25) Duffield-Lillico A. J., Dalkin B. L., Reid M. E., Turnbull B. W., Slate E. H., Jacobs E. T., Marshall J. R., Clark L. C., BJU Int., 91, 608-612 (2003).

26) Hintze K. J., Wald K. A., Zeng H., Jeffery E. H., Finley J. W., J. Nutr. 133, 2721-2727 (2003).

27) Itoh K., Wakabayashi N., Katoh Y., Ishii T., Igarashi K., Engel J. D., Yamamoto M., Genes Dev., 13, 76-86 (1999).
28) Ramos-Gomez M., Kwak M. K., Dolan P. M., Itoh K., Yamamoto M., Talalay P., Kensler T. W., Proc. Natl. Acad. Sci. U.S.A., 98, 34103415 (2001).

29) Nguyen T., Sherratt P. J., Pickett C. B., Annu. Rev. Pharmacol. Toxicol., 43, 233-260 (2003).

30) Kim M. R., Lee J. Y., Lee H. H., Aryal D. K., Kim Y. G., Kim S. K., Woo E. R., Kang K. W., Food Chem. Toxicol., 44, 1299-1307 (2006).

31) Wu C. C., Hsu M. C., Hsieh C. W., Lin J. B., Lai P. H., Wung B. S., Life Sci., 78, 2889-2897 (2006)

32) Guengerich F. P., Shimada T., Chem. Res. Toxicol., 4, 391-407 (1991).

33) Helsby N. A., Chipman J. K., Gescher A., Kerr D., Food Chem. Toxicol., 36, 375-382 (1998).

34) Catterall F., McArdle N. J., Mitchell L., Papayanni A., Clifford M. N., Ioannides C., Food Chem. Toxicol., 41, 1141-1147 (2003). 